\title{
Knowledge spillovers and new ventures' export orientation
}

\author{
Dirk De Clercq · Jolanda Hessels • \\ André van Stel
}

Accepted: 13 July 2008/Published online: 5 September 2008

(C) The Author(s) 2008. This article is published with open access at Springerlink.com

\begin{abstract}
We draw on the knowledge spillover literature to suggest that a country's proportion of export-oriented new ventures represents an outcome of knowledge spillovers that stem from foreign direct investment (FDI) and international trade (export spillovers) as well as a source of knowledge spillovers (entrepreneurship spillovers). To test the hypotheses, we use macrolevel data from 34 countries during the period 2002-2005. We find that the relationship between FDI and international trade on the one hand and a country's proportion of exportoriented new ventures on the other differs for
\end{abstract}

D. De Clercq

Brock University, 500 Glenridge Avenue, St. Catharines, ON, Canada L2S 3A1

e-mail: ddeclercq@brocku.ca

J. Hessels $(\bowtie) \cdot$ A. van Stel

EIM Business and Policy Research, P.O. Box 7001, 2701 AA Zoetermeer, The Netherlands

e-mail: joh@eim.nl

A. van Stel

e-mail: ast@eim.nl

J. Hessels

Erasmus University Rotterdam, Rotterdam,

The Netherlands

A. van Stel

University of Amsterdam, Amsterdam, The Netherlands higher- and lower-income countries. In addition, a country's proportion of export-oriented new ventures affects the subsequent emergence of new businesses.

Keywords Knowledge spillovers - Export ·

Country-level entrepreneurship

JEL Classifications $\mathrm{F} 10 \cdot \mathrm{F} 21 \cdot \mathrm{F} 23 \cdot \mathrm{L} 26 \cdot \mathrm{O} 57$

\section{Introduction}

Evidence indicates that the number of international new ventures, that is, ventures that view their operating domain as international at or near their inception, is increasing in many countries around the world (Moen 2002; Rennie 1993); in response, a wealth of research investigates factors that drive new venture internationalization (Autio 2005; Rialp et al. 2005). Research on international new ventures mainly concentrates on exporting, a common entry mode that young entrepreneurial firms use to internationalize (e.g., Burpitt and Rondinelli 2000; Campbell 1996; Zahra et al. 1997), but knowledge about why some countries have more export-oriented new ventures than others and whether and how export-oriented new ventures contribute to macroeconomic outcomes remains limited. We address such issues by investigating macrolevel 
antecedents and outcomes of a country's proportion of export-oriented new ventures. ${ }^{1}$ In particular, we argue that the proportion of export-oriented new ventures represents both an outcome and a source of knowledge spillovers. Furthermore, current understanding of international new ventures relies mainly on case studies or single-country samples, despite the need to track and study international new ventures in multiple countries (Coviello and Jones 2004; Oviatt and McDougall 1997). Therefore, we consider 34 countries over a 4-year period to uncover trends across different economies.

Entrepreneurship literature examining the early entry of new firms into foreign markets relates internationalization mainly to individual-level factors, such as entrepreneurs' international experience (Bloodgood et al. 1996; McDougall et al. 1994; Oviatt and McDougall 1995), or firm-level factors, such as entrepreneurial orientation (Sapienza et al. 2005) or a technology or knowledge base (Autio et al. 2000; Keeble et al. 1998). Whereas this literature acknowledges the importance of macrolevel environmental conditions (e.g., economic integration, transportation advances) to explain the emergence of international start-ups (Bloodgood et al. 1996; Knight and Cavusgil 1996; Oviatt and McDougall 1994; Rennie 1993), empirical contributions generally fail to include macrolevel factors as possible determinants of new ventures' international orientation. We argue that two important categories of macrolevel factors may serve as determinants of new ventures' export orientation: foreign direct investment (FDI) and international trade. Recent research suggests that FDI and international trade offer likely sources of export spillovers (Aitken et al. 1997; Banga 2003; Greenaway et al. 2004; Kneller and Pisu 2007; Terjesen et al. 2008), which take place when knowledge about foreign markets or other knowledge that is useful for operating in foreign markets (e.g., technological knowledge) transfers from one economic actor to another or competition forces actors to become more productive through exporting (Kneller and Pisu

\footnotetext{
1 We focus precisely on the proportion of new ventures relative to the total number of new ventures that target above $25 \%$ of customers in foreign countries (Moen 2002). For parsimony, we use the shortened term "proportion of exportoriented new ventures" hereafter.
}

2007). Building on the literature on export spillovers, we posit that a country's level of inward and outward FDI, export, and import positively relates to the share of new ventures that focus on serving customers abroad. Furthermore, we speculate that export spillover effects may depend on the country's capacity to absorb such spillovers (Borensztein et al. 1998; Durham 2004; Görg and Greenaway 2004; Gugler and Brunner 2007) and, more specifically, that higher-income countries may benefit more from such spillovers than their lower-income counterparts.

In addition to studying macrolevel antecedents of new ventures' export orientation, we examine a possible consequence of such export orientations, namely, an increase in the number of new businesses. Few empirical studies focus on the possible economic contributions of international new ventures. Some investigate the impact of early internationalization on growth and profitability (Autio et al. 2000; Bloodgood et al. 1996; McDougall and Oviatt 1996; Zahra et al. 2000) but typically at the firm level. We instead argue that exportoriented new ventures within a country may generate spillovers that encourage the set up of (more) new businesses within the country's borders (entrepreneurship spillovers). We suspect that export-driven new ventures may be an important source of knowledge spillovers, because such ventures tend to be innovative and have high human capital levels (Bloodgood et al. 1996), and thus serve as role models for aspiring entrepreneurs (Davidsson and Honig 2003). Thus, we add to literature that suggests that the nature of early-stage activity may provide an important source of spillovers (Audretsch and Keilbach 2004; Parker 2005).

The scope of this article encompasses whether we can identify a relationship at the macrolevel: (1) among inward FDI, outward FDI, and international trade on the one hand and the proportion of export-oriented new ventures on the other hand and, in turn, (2) between the proportion of exportoriented new ventures and a country's total level of entrepreneurial activity. Thus, though we draw from the economics literature on knowledge spillovers to predict and interpret these macrolevel relationships, we leave it for further research to investigate, at the microlevel, how such knowledge spillovers take place among individual economic actors. 


\section{Theoretical background}

The term "spillover" pertains to the transfer of knowledge across economic players; such spillovers may enable important productivity gains (Coe and Helpman 1995; Jaffe et al. 1993; Marshall 1920). According to endogenous growth theory, a country's economic growth stems from the endogenous development of knowledge through spillover effects across economic actors (Romer 1986). Spillovers or knowledge externalities allow firms to acquire knowledge from other economic players without having to pay for it in a formal market transaction (Acs et al. 1994; Bernstein and Nadiri 1988). They take place from one firm to another partially because knowledge represents a public good (Grossman and Helpman 1991) or a "nonrival" asset that different economic actors may use simultaneously in different locations (Romer 1990). Furthermore, knowledge generally is not excludable, so knowledge-generating firms have difficulty extracting compensation in return for others' use of their knowledge (Grossman and Helpman 1991). Thus, knowledge-generating firms cannot fully appropriate or internalize the returns on knowledge investments, and some returns spill over to benefit others as well.

\subsection{Export spillover effects and new ventures' export orientation}

Many studies on knowledge spillovers focus on productivity spillovers (for an overview, see Görg and Greenaway 2004), including those across country borders. Grossman and Helpman (1991) explain that cross-border movements of capital and trade affect economic growth through their related knowledge spillovers. Prior work on the role of spillovers also devotes particular attention to inward FDI, in which knowledge flows from foreign multinational enterprises (MNEs) to the host country's domestic firms are studied (e.g., Feinberg and Majumdar 2001; Fosfuri et al. 2001). Such research generally assumes that MNEs possess superior firm-specific assets, such as management know-how or technologies, when they enter foreign markets (Dunning 1981; Hymer 1976), but they face the challenge of protecting these advantages against other firms in the countries in which they operate (Görg and Greenaway 2004; Kneller and Pisu 2007).
In addition to traditional literature on productivity spillovers, an emerging body of research focuses on the effect of spillovers on the export decision of domestic firms, or export spillovers (e.g., Aitken et al. 1997; Banga 2003; Greenaway et al. 2004; Kneller and Pisu 2007). Domestic firms may be more inclined to engage in export activities if they are exposed to other economic actors' international activities (Greenaway et al. 2004). Aitken et al. (1997), for instance, note a spillover effect from foreign MNEs to domestic export activity in Mexican manufacturing industries and show that the dominance of foreign MNEs in a particular industry sector increases the probability that domestic firms in that sector also export. Similarly, Greenaway et al. (2004) use UK data to show that foreign MNEs' export activities have a positive effect on a domestic firm's export probability.

This study focuses on such export spillover effects, with the assumption that export spillovers should be particularly relevant in the context of new ventures because emerging firms are more likely to benefit from (external) knowledge spillovers than their more established counterparts (Acs et al. 1994; Henderson and Clark 1990). Whereas in mature firms external knowledge spillovers may be less important because they must compete with internal knowledge spillovers that result from prior and ongoing operations, the knowledge production function of new ventures likely gets influenced by the input provided by external organizations or activities (Acs et al. 1994). Furthermore, export market entry requires upfront sunk costs for firms to sell products or services in foreign markets, such as the costs associated with establishing distribution and logistic channels and acquiring information about the tastes of foreign customers and market structures (Greenaway et al. 2004; Requena-Silvente 2005). These sunk costs are higher for new ventures compared with their more established counterparts, because they confront resource constraints more directly (Requena-Silvente 2005). Accordingly, new ventures are more likely to depend on and benefit from external spillovers.

To understand the mechanisms of how spillovers occur across country borders, extant research identifies different spillover channels, specifically with respect to the case of inward FDI. First, market access spillovers occur through commercial links between foreign MNEs and local suppliers, which 
give the local suppliers preferential access to new technological capabilities and foreign customers' product design and quality preferences (Aitken et al. 1997; Barrell and Pain 1997; Blomström and Kokko 1998). Second, a demonstration or imitation effect prompts domestic firms to copy foreign MNEs' organizational practices, either through formal interfirm collaborations or more informal channels (Wang and Blomström 1992). Third, when local employees gain important skills while working for a foreign MNE, a training effect transfers those skills to other organizations (Fosfuri et al. 2001). Fourth, foreign entrants may increase local competition by, for example, infusing new technologies into the local market and acting as competitive catalysts (Barrell and Pain 1997; Cantwell 1989; Chuang and Lin 1999; Glass and Saggi 1998). For the purpose of this research, we argue that these different channels of cross-border spillovers may clarify how not only inward FDI but also other sources of knowledge spillovers-such as outward FDI and international trade-influence a country's proportion of exportoriented new ventures.

\subsection{New ventures' export orientation and} entrepreneurship spillovers

In addition to examining the antecedents of new ventures' export orientation, we examine whether export-oriented new ventures generate spillovers that affect a country's economic activity, particularly with regard to the creation of new businesses within the country's borders. This focus on entrepreneurship spillovers matches recent research that argues entrepreneurial activity (i.e., new business creation) results from the exploitation of knowledge that incumbent firms have not fully appropriated or commercialized (Acs et al. 2006, 2007). Specifically, when an economic agent with a new idea cannot convince decision makers within the firm to pursue the idea, the agent may start a new business in an attempt to appropriate the new knowledge. This new knowledge thus spills over from the agent to a new business in which it gets commercialized (Audretsch and Keilbach 2004). Hence, a country's total level of entrepreneurial activity represents an important outcome of spillover effects. Similarly, we extend existing literature by suggesting that new business creation may result from spillovers from not only incumbent (large) firms but also other new ventures; in particular, we argue that export-oriented new ventures present a source of spillovers that may affect the emergence of additional new businesses in the country.

\section{Hypotheses}

3.1 Inward FDI and the proportion of exportoriented new ventures

Foreign MNEs (through inward FDI) may act as catalysts of new ventures' export orientation for several reasons. First, foreign MNEs can facilitate exports among new ventures through the direct channel established when the latter serve as suppliers or subcontractors for the MNEs. Commercial linkages with foreign MNEs thus provide new ventures with knowledge about new technological developments and foreign market conditions; over time, this knowledge may prompt new ventures to export (Blomström and Kokko 1998). Foreign MNEs can also pave the way for new ventures to enter the same export markets, either because the MNEs have created adequate transport infrastructures or because they disseminate knowledge about specific foreign markets that new ventures can use directly. Second, demonstration effects may lead new ventures to use foreign MNEs as role models for their own decision to engage in exporting (Powell and DiMaggio 1991). Third, spillover effects from foreign MNEs may take place when new ventures acquire relevant human capital. It is difficult for foreign MNEs to lock in their human capital (Djankov and Hoekman 1999; Dunning 1981; Fosfuri et al. 2001), but because they often require a skilled labor force, they organize training for local employees. When those employees move away and start their own businesses, the internationalization skills they gained while working for the foreign affiliate spill over to new ventures (Gerschenberg 1987). Fourth, inward FDI infuses new technologies in host countries (Barrell and Pain 1997), and foreign affiliates might replace inefficient firms in the host country (Narula and Marin 2003). The increased competition should provide local startups with the capabilities and incentives to expand the geographical scope of their activities; that is, the increase in competition that occurs as a result of 
foreign entry may prompt new ventures to expand their horizons and engage in export activities.

Hypothesis 1 The greater a country's inward FDI, the greater its proportion of export-oriented new ventures.

In addition, spillover effects may be more pronounced in higher-income versus lower-income countries. The exploitation of spillovers relates to a country's structural characteristics, especially its absorptive capacity (Durham 2004; Görg and Greenaway 2004). Spillover effects from inward FDI materialize more easily when the host country has a minimum stock of human capital or level of economic development (Blomström et al. 1994; Borensztein et al. 1998). Extant literature suggests that when the technology gap between the investing country and the host country is not too large-which indicates that firms in the host country have sufficient capacity to absorb advanced technologies-the host economy can benefit from positive spillovers (Borensztein et al. 1998; Görg and Greenaway 2004). Similarly, we reason that lower-income countries may have limited capacity (e.g., human capital) to absorb exporting knowledge provided by foreign MNEs. Furthermore, in lower-income countries, positive spillovers from inward FDI to new ventures' export orientation may be hampered because inward FDI contributes to the development of scale economies and thus to the economic activities of larger, incumbent firms rather than those of new ventures (Acs et al. 1994; Wennekers et al. 2005).

Hypothesis 2 The positive spillover effect from a country's inward FDI to the export orientation of its new ventures is more pronounced in higher-income than in lower-income countries.

\subsection{Outward FDI and the proportion of export- oriented new ventures}

Although literature on the impact of FDI on a host country's economic activities focuses mostly on spillover effects stemming from inward rather than outward FDI, domestic MNEs should also affect a country's proportion of export-oriented new ventures (Blomström and Kokko 1998). The presence of these domestic MNEs in foreign countries may familiarize foreign customers with common business practices in the MNEs' home country, which could create a pull effect (Nagel 2003). Furthermore, the rationale for the spillover effects of domestic MNEs to new ventures parallels arguments associated with foreign MNEs (Blomström and Kokko 1998). First, spillovers may occur if a domestic MNE adapts its products to local conditions abroad and shares this adaptation with its suppliers (e.g., new ventures) in its home country (Aitken et al. 1997). Second, the spillovers obtained through demonstration, training, and competition effects, as outlined in the argumentation leading up to hypothesis 1, may work in a similar fashion for domestic MNEs. For example, in terms of the training effect, a manager of a foreign subsidiary may return to the home country and become an (export-oriented) entrepreneur (Cantwell and Hodson 1991; Kogut and Chang 1991). Third, the structural changes that take place in the new ventures' home country because of the wider presence of domestic MNEs (i.e., when there is more outward FDI) may positively influence new ventures' export orientation. Specifically, an increase in outward FDI should shift the home country toward economic activities that entail greater productivity (Blomström and Kokko 1998); this increased productivity may then force new ventures to increase the overall quality of their products, which ultimately should increase their propensity to export.

Hypothesis 3 The greater a country's outward FDI, the greater its proportion of export-oriented new ventures.

Similar to the argumentation used for the effect of inward FDI, we also speculate that the beneficial spillovers from outward FDI to new ventures' export orientation materialize more easily in higher- versus lower-income countries. That is, lower-income economies may lack the capacity to absorb spillovers from outward FDI, because their new ventures have relatively lower levels of human capital, which they need to engage in exports (Bloodgood et al. 1996), or they may participate in low-technology sectors for which export opportunities are limited (Durham 2004; Görg and Greenaway 2004).

Hypothesis 4 The positive spillover effect from a country's outward FDI to the export orientation of its new ventures is more pronounced in higher-income than in lower-income countries. 
3.3 International trade and the proportion of export-oriented new ventures

In the previous hypotheses, we posit that FDI, both inward and outward, offers an important source of knowledge spillovers; we now consider how a country's level of international trade may affect its proportion of export-oriented new ventures. We thus extend prior research that indicates a link between international trade (i.e., export and import) and a country's productivity, based on the transfer of knowledge across country borders (Findlay 1984; Grossman and Helpman 1991; Sjoholm 1996). For the purpose of this study, we hypothesize that a country's levels of export and import represent two additional sources of knowledge spillovers that influence new ventures' export orientation.

A country's overall export level should have a positive effect on its proportion of export-oriented new ventures, particularly through the demonstration effect (Greenaway et al. 2004). That is, simple imitation may play an important role in shaping new ventures' decision to export when they are surrounded by many other firms that engage in export activities. Similarly, the positive relationship between a country's export level and the proportion of export-oriented new ventures mirrors institutional theory that suggests firm behavior results from mimetic isomorphism, or economic actors' tendency to imitate decisions or practices of peers (Powell and DiMaggio 1991).

Spillovers stemming from a country's level of export should also be significant for new ventures because they minimize the challenge of assessing the costs and benefits associated with export activities (Johanson and Vahlne 1990). When new ventures come in contact with existing exporters, they gain information about how to become a successful exporter more easily, which diminishes their uncertainty regarding the pros and cons of exporting (Burpitt and Rondinelli 2000; Ogbuehi and Longfellow 1994); for example, information that foreign customers provide to incumbent suppliers regarding how to facilitate the production of goods and services they plan to buy could spill over to new ventures through formal partnerships with exporting firms (e.g., strategic alliances) or more informal channels (e.g., trade associations, publications) (De Clercq et al. 2005; Zahra et al. 2000). The previously mentioned training effect may also be relevant in this context (Fosfuri et al. 2001); economic actors who directly or indirectly participate in exporting activities should be stimulated to enter foreign markets when they establish their own companies (McDougall et al. 1994). A final mechanism that may explain the positive relationship between a country's overall level of export and the proportion of its exportoriented new ventures refers to existing relationships between domestic suppliers and foreign customers, which may create a sense of familiarity among foreign customers regarding the country in which new ventures operate and its business practices in particular (Blomström and Kokko 1998; Nagel 2003). This familiarity may increase new ventures' anticipation of success when they consider the possibility of export activities.

Hypothesis 5 The greater a country's export level, the greater its proportion of export-oriented new ventures.

Again, and similar to the arguments given for the spillovers from FDI, we expect that the positive externalities from a country's overall export levels to the export orientation of its new ventures may be constrained in lower-income countries because of their limited absorptive activity, as reflected in their low levels of human capital and the nature of their industry structure (e.g., few high-value-added sectors).

Hypothesis 6 The positive spillover effect from a country's export level to the export orientation of its new ventures is more pronounced in higher-income than in lower-income countries.

We also posit a positive effect between a country's level of import activity and its proportion of exportoriented new ventures. Import activity reflects the amount of knowledge exchange that takes place between domestic producers and foreign suppliers. Prior research on the spillover effects of import mainly focuses on the role of technology transfer; empirical evidence demonstrates that imports provide an important source for the transfer of new technologies across country borders (e.g., Blalock and Veloso 2005; Coe and Helpman 1995; Feinberg and Majumdar 2001; Glass and Saggi 1998). We extend this research by arguing that spillover effects from imports relate not only to technology transfer but also to other types of knowledge that may induce export 
activities. New ventures could benefit from their country's import activities if a foreign producer exchanges knowledge about its home market as a sales tool for existing customers (Coe and Helpman 1995). If such knowledge spills over to a country's new ventures through collaborations with and exposure to more knowledgeable domestic players, the new ventures obtain a better understanding of the foreign producers' specific country context and thus achieve a better position from which to find foreign customers. In short, foreign producers may reveal information about their own country's unique characteristics as a sales tool, in which case this knowledge accumulates indirectly within the country in which the new ventures operate. Over time, accumulated knowledge about particular countries should decrease uncertainty related to undertaking business activities in foreign countries and enhance the proportion of export-oriented new ventures.

Hypothesis 7 The greater a country's import level, the greater its proportion of export-oriented new ventures.

Based on similar reasoning with respect to the role of export spillovers from FDI and export, we speculate that the spillovers from import are more pronounced in higher- versus lower-income countries.

Hypothesis 8 The positive spillover effect from a country's import level to the export orientation of its new ventures is more pronounced in higher-income than in lower-income countries.

\subsection{Export-oriented new ventures and total level of entrepreneurial activity}

Finally, we expect that the extent to which a country's new ventures are oriented toward exports is not only a consequence of spillover effects but also provides a specific source of spillovers that influences the emergence of new businesses in the country. That is, the nature of early-stage activity itself can be an important source of spillovers (Parker 2005). In making this claim, we draw from literature that emphasizes the role of macrolevel factors to explain cross-country differences in entrepreneurship (Noorderhaven et al. 2004; Verheul et al. 2002). Specifically, previous literature highlights the role of demand-side factors (e.g., country's industrial structure) and supply-side factors (e.g., skills and preferences) in shaping entrepreneurs' willingness or ability to act on new business opportunities and create the opportunities for such start-up activity. A specific supply factor that influences the emergence of new businesses within a country may be the export orientation of its (existing) new ventures. First, exporting new ventures have preferential access to knowledge related to foreign markets and technologies (Autio et al. 2000; Hessels 2007; Zahra et al. 2000), and this knowledge may generate novel insights into unexploited opportunities for new businesses (De Clercq et al. 2005; Shane and Venkataraman 2000). Second, new ventures focusing on export may act as extraordinary role models for aspiring entrepreneurs (Davidsson and Honig 2003). Consistent with the premises underlying institutional theory, individual economic actors may imitate the behavior of highly visible and successful peers, including export-oriented new ventures (Powell and DiMaggio 1991). Such imitation may then provide support and legitimacy to entrepreneurship as a career choice, resulting in the creation of more new businesses within the country.

Hypothesis 9 The greater a country's proportion of export-oriented new ventures, the greater its (subsequent) total level of entrepreneurial activity.

\section{Methodology}

\subsection{Data and sample}

We draw data from various sources. To determine a country's proportion of export-oriented new ventures and total level of entrepreneurial activity (i.e., dependent variables), we collect information from the Global Entrepreneurship Monitor (GEM; Reynolds et al. 2005; see also Acs et al. 2008a, for more elaborate information on the GEM project). Various organizations [e.g., the World Trade Organization (WTO), the Organization for Economic Cooperation and Development (OECD), the United Nations (UN), and Eurostat] publish international comparative statistics about exports for many countries, but virtually no official international comparative export statistics relate specifically to new ventures. In this respect, the 
GEM initiative fills an important gap by providing a harmonized measure of new ventures' export orientations across countries. For our independent variables, we draw data about a country's FDI from the Foreign Direct Investment database maintained by the United Nations Conference on Trade and Development (UNCTAD) and gather information about each country's export and import levels from the World Bank. Finally, we include several control variables in our models and obtain these data from several sources, including the Global Competitiveness Report and the World Competitiveness Yearbook.

In essence, our data set includes annual data pertaining to 34 countries over a 4-year period (2002-2005). The sample of included countries is limited to those that participated in GEM during 20022005 . $^{2}$ Furthermore, because not all countries participated in GEM in each year and because we note missing data for some independent variables, our analyses are based on 80 observations distributed across 34 countries. Finally, we assign countries to higher- or lower-income categories on the basis of their overall prosperity. ${ }^{3}$

\subsection{Measures}

\subsubsection{Dependent variables}

We measure total level of (early-stage) entrepreneurial activity (2002-2005) using GEM's total early-stage entrepreneurial activity (TEA) index, ${ }^{4}$ which assesses the proportion of a country's population between the ages of 18 and 64 years who are either in the start-up phase or manage/own a business that is less than 42 months (i.e., 3.5 years) of age. ${ }^{5}$

\footnotetext{
2 The countries are Argentina, Australia, Belgium, Brazil, Canada, Chile, China, Denmark, Finland, France, Germany, Greece, Hong Kong, Hungary, Iceland, India, Ireland, Israel, Italy, Japan, Korea, Mexico, The Netherlands, New Zealand, Norway, Poland, Slovenia, South Africa, Spain, Sweden, Switzerland, Thailand, the UK, and the USA.

${ }^{3}$ Specifically, following the classification used by the World Bank, the lower-income category includes "low-income economies," "lower-middle-income economies," and "uppermiddle-income economies," while the higher-income category includes "high-income economies."

4 The TEA index is the most widely known index generated by GEM (Minniti et al. 2006; Reynolds et al. 2005).

5 We count those engaged in both activities in a given year only once (Reynolds et al. 2005).
}

The TEA index thus assesses, in a given year, the total level of (early-stage) entrepreneurial activity within a country, irrespective of its nature. Reynolds et al. (2005) provide empirical support for the validity of the TEA index by comparing it with national administrative data on firm birth rates and support its reliability by calculating the correlation of countries' TEA rates over different years. The TEA is based on information collected through adult population surveys conducted by telephone or face to face. See also Acs et al. (2008b), who provide a more elaborate discussion of the TEA when comparing it with the World Bank business entry data.

To measure the proportion of export-oriented new ventures (2002-2005), we consider the percentage of a country's (early-stage) entrepreneurs (as defined by the TEA index) involved in substantial export activity. Specifically, we assess the proportion of new ventures, relative to the total number of new ventures, that stated that at least $26 \%$ of their customers were located in foreign countries (Reynolds et al. 2005). ${ }^{6}$ With this unique measure, the GEM project provides a first attempt to create cross-country data pertaining to the extent to which new ventures orient toward exports. As one of their defining characteristic, international new ventures are international at their inception (Knight and Cavusgil 2004; Oviatt and McDougall 1997). Because of the challenge associated with observing a firm's activities at its inception, extant research typically defines international new ventures pragmatically as those that make foreign market commitments within a relatively long period after their founding, such as 6 or 8 years (Coviello and Jones 2004; Oviatt and McDougall 1997). Furthermore, to capture international activity at the time of inception, researchers must define the exact point at which the business was founded (Katz and Gartner 1988; Reynolds and Miller 1992). In this regard, Oviatt and McDougall (1997) suggest that the time of business founding occurs when the first serious planning for the business takes place. Accordingly, our measure of new ventures' export orientation includes entrepreneurs that are currently

\footnotetext{
${ }^{6}$ Our choice to include only new ventures with a substantial focus on exports (i.e., more than $25 \%$ foreign customers) is guided by previous studies in international entrepreneurship, in which high-level exporters are commonly defined as having export sales of $25 \%$ or more (Moen 2002).
} 
involved in the start-up processes of their venture or have recently gone through this process. Our measure also matches recent research that suggests it is important to take into account a firm's very early phases when studying international new ventures (Coviello 2006; Moen 2002). Finally, extant research indicates that foreign market entry by new ventures often takes place within 3 years of the firm's establishment (Autio et al. 2000; McDougall and Oviatt 2000; Rennie 1993). Thus, our definition of new ventures' export orientation includes ventures that are as old as 3.5 years, which seems appropriate.

\subsubsection{Independent variables}

Inward FDI (1995-2004) reflects the percentage of a country's inward flow of foreign capital relative to its gross fixed capital formation. Outward FDI (19952004) equals the percentage of a country's outward flow of capital relative to its gross fixed capital formation. We draw both measures from UNCTAD's World Investment Report.

We use the percentage of a country's exports of goods and services relative to its gross domestic product (GDP) to measure a country's export level (1995-2004), which we obtain from the World Development Indicators database, provided by the World Bank. This measure is skewed toward larger and older firms, which undertake the vast majority of export activity (in terms of value added). Particularly in lower-income countries, the GDP created by new ventures, let alone the amount of their export activity, typically is not recorded in official statistics (Reynolds et al. 2005; Sternberg and Wennekers 2005). Therefore, it seems unlikely that the added value created by the export activities of new ventures, as captured in our GEM-based measure of new ventures' export orientation, would be recorded in the official statistics about countries' export levels. ${ }^{7}$ Hence, a positive correlation between export as a percentage of GDP and our measure of the proportion of export-oriented new ventures is by no means straightforward. Similarly, we measure a country's import level (1995-2004) as the percentage of a

\footnotetext{
7 Part of the TEA index relates to nascent entrepreneurs, which have not yet started their business (Reynolds et al. 2005); thus, for this group of entrepreneurs, official export statistics certainly do not capture (expected) export activity.
}

country's imports of goods and services relative to its GDP. This measure is also drawn from the World Development Indicators database.

\subsubsection{Control variables}

To account for alternative explanations for the variation of both of our dependent variables (i.e., proportion of export-oriented new ventures and total level of entrepreneurial activity) across countries, we include several control variables. Consistent with the eclectic framework of entrepreneurship (Verheul et al. 2002), we classify these controls into two categories: (1) demand-side factors that reflect the presence of entrepreneurial opportunities through market demand and (2) supply-side factors that entail the skills and preferences of a country's population toward new business creation.

In terms of demand-side factors, we consider employment share in manufacturing and employment share in services (2000) to represent a country's economic structure, which may influence the level and nature of the country's early-stage activity (Verheul et al. 2002). We draw this measure from the World Competitiveness Yearbook. In addition, we use a lower-income country dummy to reflect a country's overall prosperity, which may influence the level and nature of its new venture activities (Verheul et al. 2002); we code this dummy as 1 when the country belongs to the "low-income economies", "lower-middle-income economies" or the "uppermiddle-income economies" according to the World Bank classification of countries by income. To assess the annual percentage change in a country's GDP, a dynamic measure of a country's overall prosperity, we use economic growth (2002-2005), based on data from the World Economic Outlook database, provided by the International Monetary Fund. Finally, our measure of company-university cooperation (2001) assesses (on a seven-point Likert scale) the technology transfer between companies and universities and reflects a source of technological resources for entrepreneurs. This measure emerges from the World Competitiveness Yearbook.

In terms of supply-side factors, ease of access to loans (2001), measured on a seven-point Likert scale and drawn from the Global Competitiveness Report, reflects the extent to which new ventures have easy access to financial resources to support 
their activities. Furthermore, tertiary education (1997), also drawn from the Global Competitiveness Report, pertains to a country's gross tertiary enrollment rate.

For the estimation of a country's proportion of export-oriented new ventures, we include three additional control variables: Gross domestic product (logarithm) (2002-2005), drawn from the World Development Indicators database, reflects the size of a country's home market. Inflation rate (2002-2005), obtained from the World Economic Outlook database, reflects increases in consumer price levels (annual percentage changes) that make it harder for economic actors to engage in export activity (domestically, inflation often coincides with wage compensation, but such compensation is less likely at the international trade level). Change in exchange rate (2002-2005), drawn from Economic History Services (and supplemented by information from OANDA.com), is the percentage change of a country's national currency in US dollars. When the exchange rate increases, products become relatively more expensive for foreign buyers, which may hinder new ventures' export orientation. Finally, we include time dummies to control for cyclical changes in the global economic environment that may influence the level and nature of entrepreneurial activity within countries.

\subsection{Analysis}

We test our hypotheses using regression analysis. For the prediction of a country's proportion of exportoriented new ventures, we employ different time lags for the independent and control variables. First, because knowledge spillovers may take some time before they materialize (Jaffe and Trajtenberg 1998) and because the four independent variables-inward FDI, outward FDI, export, and import-fluctuate heavily over time, we average the four variables over the 6 years that span the period from $t-1$ to $t-6$. Second, we include the cyclical variables, economic growth, inflation rate, and exchange rate, contemporaneously with the dependent variables, and we capture the remaining cyclical variation by the time dummies. Third, the remaining seven controlsemployment share of manufacturing, employment share of services, lower-income country dummy, company-university cooperation, ease of access to loans, tertiary education, and $\log$ of GDP-reflect structural characteristics of an economy and thus change only slowly over time. Accordingly, we include them as time-invariant variables in the empirical analysis. ${ }^{8}$ Finally, for the prediction of a country's total level of entrepreneurial activity, we use a 1-year time lag of the "proportion of exportoriented new ventures" variable.

\section{Results}

In Table 1, we display the correlations among the study variables. The correlations between the proportion of export-oriented new ventures and the four sources of cross-border spillovers (inward FDI, outward FDI, export, and import) are significant and positive; however, high correlation coefficients mark the four independent variables, particularly between a country's export and import levels (0.98), which raises concerns about multicollinearity (Greene 2004). The correlation between export and import is so high that their effects cannot be separated in a single regression model. Therefore, we calculate the sum of export and import and label this variable "total international trade." 9

In Table 2, we present some descriptive statistics for the study's key variables in higher- versus lowerincome countries. As we might expect, the total level of entrepreneurial activity is greater in lower-income countries, whereas the proportion of export-oriented new ventures is greater in higher-income countries (Acs et al. 2004; see also Acs and Amorós 2008). Furthermore, levels of FDI and international trade are greater in higher-income versus lower-income countries, which reflects the latter's poor integration into the world economy. In particular, the low level of outward FDI for lower-income countries is striking;

\footnotetext{
$\overline{8}$ Including these time-invariant independent variables makes the use of fixed effects superfluous, because the time-invariant independent variables can explain structural country differences. Because this approach requires fewer independent variables (i.e., 7 instead of 34 country dummies), we can estimate the model coefficients more efficiently.

9 To assess the separate effects of export and import in the same model, we include a "surplus in international trade" variable, which equals the difference between a country's export and import levels, in model 8 (Table 3).
} 


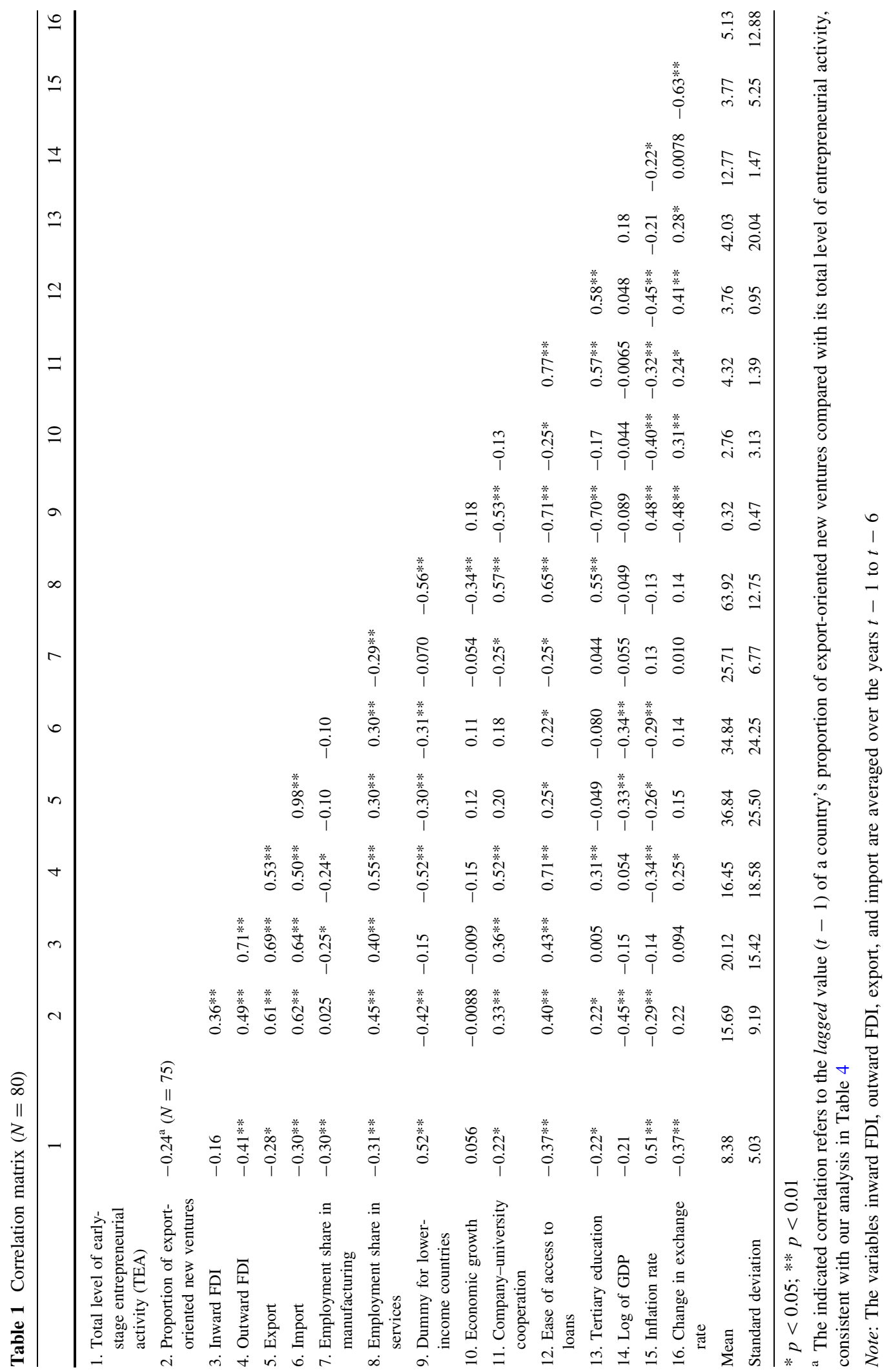


Table 2 Descriptive statistics for dependent and independent variables, by level of economic development (averages 2002-2005)

\begin{tabular}{|c|c|c|c|c|c|c|c|c|}
\hline & TEA & $\begin{array}{l}\text { Percentage of } \\
\text { export- } \\
\text { oriented } \\
\text { new ventures }\end{array}$ & $\begin{array}{l}\text { Inward } \\
\text { FDI }\end{array}$ & $\begin{array}{l}\text { Outward } \\
\text { FDI }\end{array}$ & Export & Import & $\begin{array}{l}\text { Total } \\
\text { international } \\
\text { trade }\end{array}$ & $\begin{array}{l}\text { Surplus in } \\
\text { international } \\
\text { trade }\end{array}$ \\
\hline \multicolumn{9}{|c|}{ Higher-income countries $(N=55)$} \\
\hline Mean & 6.6 & 18.3 & 21.7 & 22.9 & 42.0 & 39.8 & 81.8 & 2.2 \\
\hline $\begin{array}{l}\text { Standard } \\
\text { deviation }\end{array}$ & 3.2 & 8.2 & 17.8 & 19.1 & 28.2 & 26.7 & 54.6 & 5.2 \\
\hline Minimum & 1.48 & 0.0 & 0.49 & 1.00 & 10.6 & 9.4 & 20.0 & -8.7 \\
\hline Maximum & 14.5 & 43.2 & 66.5 & 56.7 & 143.0 & 137.7 & 280.7 & 14.4 \\
\hline \multicolumn{9}{|c|}{ Lower-income countries $(N=25)$} \\
\hline Mean & 12.2 & 10.0 & 16.7 & 2.2 & 25.6 & 23.9 & 49.5 & 1.69 \\
\hline $\begin{array}{l}\text { Standard } \\
\text { deviation }\end{array}$ & 6.1 & 8.6 & 7.2 & 3.1 & 12.7 & 12.5 & 24.9 & 4.0 \\
\hline Minimum & 2.5 & 0.95 & 2.9 & -0.74 & 9.4 & 11.2 & 20.6 & -4.9 \\
\hline Maximum & 27.3 & 32.5 & 31.9 & 12.1 & 63.0 & 64.4 & 127.4 & 10.9 \\
\hline
\end{tabular}

Notes: TEA is the number of (early-stage) entrepreneurs as a percentage of the adult population; \% export-oriented new ventures is the number of (early-stage) entrepreneurs stating that $26 \%$ or more of their customers are foreign as a percentage of the total (earlystage) entrepreneurs; and inward FDI, outward FDI, export, and import are averaged over the years $t-1$ to $t-6$

they have only recently begun to engage in outward FDI (UNCTAD 2006).

The results of the regressions predicting a country's proportion of export-oriented new ventures (i.e., export spillover hypotheses) appear in Table 3. First, model 1 includes only the control variables and reveals that the proportion of export-oriented new ventures is influenced positively by the country's employment share in manufacturing and services but negatively by GDP (logged) and the inflation rate. Second, models 2-7 summarize the results when we enter the various sources of export spillovers (inward FDI, outward FDI, and international trade) into separate models. Specifically, models 2, 4, and 6 do not discriminate between higher- and lower-income countries (to test hypotheses 1,3,5, and 7), and models 3,5, and 7 multiply each of the sources of knowledge spillovers with a dummy variable that reflects whether a country belongs to the higher- or lower-income category (to test hypotheses $2,4,6$, and 8 ). ${ }^{10}$

\footnotetext{
${ }^{10}$ Likelihood ratio tests show that the improvement of the model fit is significant for inward FDI (model 3 versus model 2) but not significant for outward FDI and total international trade. Nevertheless, we observe substantial differences between the coefficients for higher- and lowerincome countries for both outward FDI and international trade. We also perform a likelihood ratio test to compare model 8
}

Model 2 indicates no effect of inward FDI on the proportion of export-oriented new ventures and thus a lack of support for hypothesis 1 . However, model 3 reveals that this lack of effect may be explained by the opposite role that inward FDI plays in higherversus lower-income countries. Specifically, whereas inward FDI has a positive effect on the proportion of export-oriented new ventures in higher-income countries, its effect is negative in those with lower incomes. This finding provides partial support for hypothesis 2 , in that we did not anticipate the negative effect for lower-income countries. Furthermore, model 4 shows a positive effect of outward FDI on the proportion of export-oriented new ventures (in support of hypothesis 3), and this positive effect manifests itself only in higher-income countries (model 5, in support of hypothesis 4). Similarly, international trade has a positive effect on the proportion of export-oriented new ventures

Footnote 10 continued with a specification that does not distinguish between effects for the two country classifications. The likelihood ratio value for the latter specification (not reported) is -245.0 whereas that of model 8 is -237.6 (Table 3 ). Thus, the test statistic equals 14.8. Because the critical value at the $1 \%$ level is 13.3 (four degrees of freedom), the test shows that allowing for different effects for higher- and lower-income countries significantly improves the model fit. 


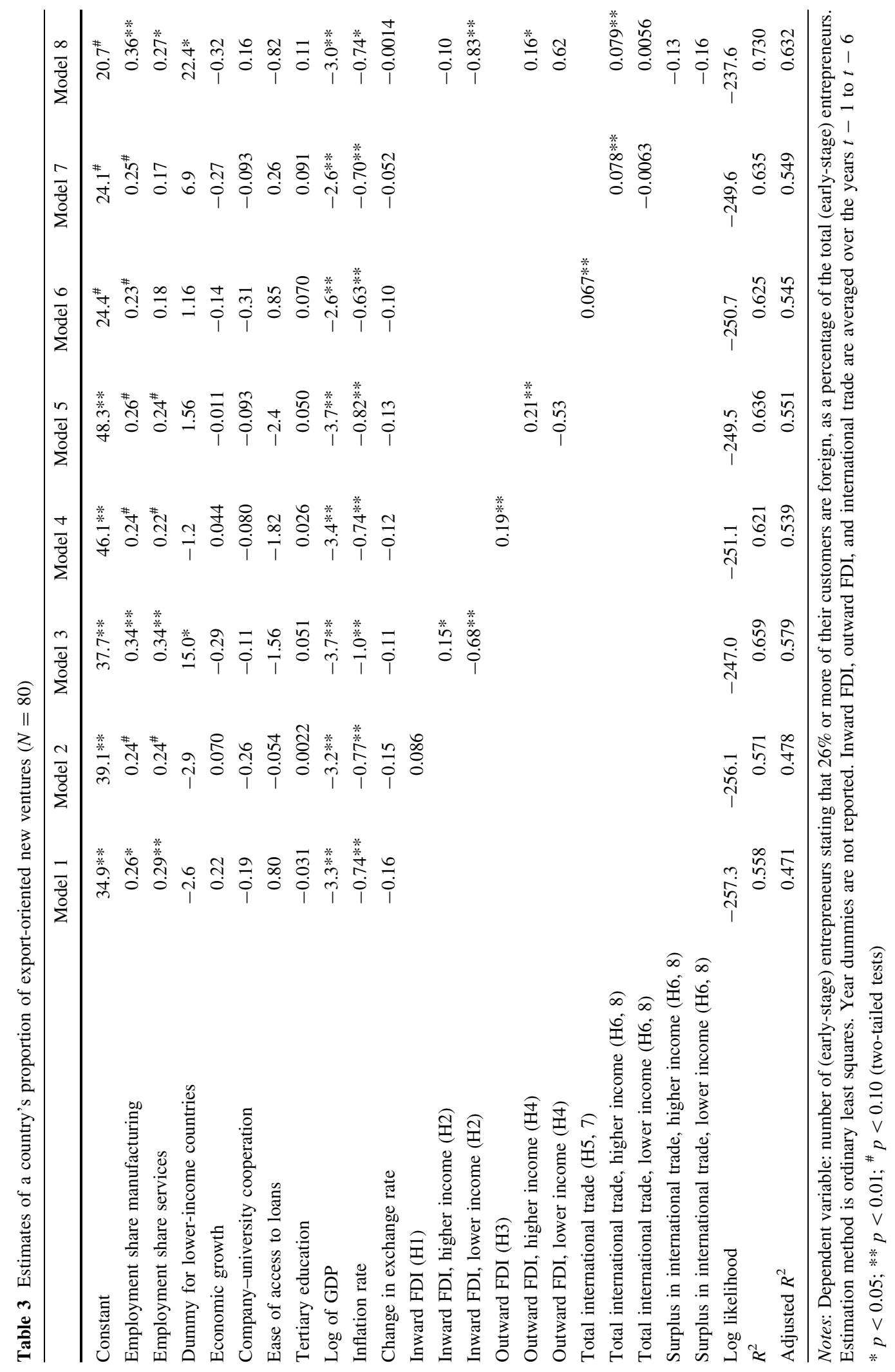


Table 4 Estimates of a country's total level of entrepreneurial activity $(N=75)$

\begin{tabular}{|c|c|c|c|}
\hline & Model 9 & Model 10 & Model 11 \\
\hline Constant & 14.5 & 14.2 & $18.5^{*}$ \\
\hline Employment share manufacturing & $-0.23 *$ & $-0.22 *$ & $-0.31 * *$ \\
\hline Employment share services & -0.14 & -0.14 & $-0.23 *$ \\
\hline Dummy for lower-income countries & $4.0^{*}$ & $3.8^{*}$ & $5.6 * *$ \\
\hline Economic growth & $0.82 * *$ & $0.83 * *$ & $0.69 *$ \\
\hline Company-university cooperation & -0.31 & -0.29 & -0.54 \\
\hline Ease of access to loans & 0.42 & 0.42 & 0.39 \\
\hline Tertiary education & $0.12 * *$ & $0.12 * *$ & $0.16^{* *}$ \\
\hline Proportion of export-oriented new ventures, (year $t-1)(\mathrm{H} 9)$ & & -0.015 & $0.20^{\#}$ \\
\hline Estimation method & OLS & OLS & IV \\
\hline Endogenous explanatory variable & & & $\begin{array}{l}\text { Proportion of export-oriented } \\
\text { new ventures (year } t-1 \text { ) }\end{array}$ \\
\hline Instrument used & & & Log of GDP \\
\hline$R^{2}$ & 0.491 & 0.492 & 0.346 \\
\hline Adjusted $R^{2}$ & 0.421 & 0.413 & 0.243 \\
\hline
\end{tabular}

Notes: Dependent variable: number of (early-stage) entrepreneurs as a percentage of the adult population (i.e., TEA index). Year dummies not reported

$* p<0.05 ; * * p<0.01 ;{ }^{*} p<0.10$ (one-tailed tests)

(model 6), which is only present in higher-income countries (model 7), in tentative support of hypotheses $5,6,7$, and 8 .

For a more rigorous test of the export spillover hypotheses, in model 8 , we include the three sources of export spillovers simultaneously, as well as the "surplus in international trade" variable to separate the effects of export versus import. The results show positive effects of outward FDI and total international trade in higher-income countries and a negative effect of inward FDI in lower-income countries. The surplus in international trade variable remains insignificant in both types of countries.

Finally, in Table 4, we assess the effect of a country's proportion of export-oriented new ventures on its total level of entrepreneurial activity. ${ }^{11}$ Model 9, which includes only the controls, shows that a country's economic growth and tertiary

\footnotetext{
11 The number of observations in Table $4(N=75)$ differs from that in Table $3(N=80)$. The 1-year time lag used in Table 4 results in a loss of observations for the proportion of export-oriented new ventures variable, but Table 4 also gains observations for which a spillover variable (i.e., FDI, international trade) was missing in Table 3.
}

education enrollment rate positively influence total entrepreneurial activity, whereas employment share in manufacturing has a negative effect. Model 10 also shows that the proportion of export-oriented new ventures does not have a significant effect, but as Table 3 and our hypotheses suggest, this variable is not exogenous. In particular, the log of GDP (i.e., size of the home market) has a strong impact on the proportion of export-oriented new ventures, and therefore, the ordinary least-squares estimates in model 10 likely are biased (Greene 2004). Accordingly, in model 11, we estimate a country's total level of entrepreneurial activity using the instrumental variable estimation technique (Greene 2004). ${ }^{12}$ Consistent with our expectations in hypothesis 9 , we find a positive, albeit weak, effect of a country's

\footnotetext{
$\overline{12}$ In model 11 , the number of instruments equals the number of endogenous explanatory variables (i.e., one), so the model is exactly identified (Greene 2004). As a robustness test, we tried several alternative estimations, with FDI and the trade variables as additional instruments. All estimations support the validity of the applied instruments, and the coefficient for the proportion of export-oriented new ventures variable remains similar to that reported in model 11 (Table 4).
} 
proportion of export-oriented new ventures on its total level of entrepreneurial activity $(p=0.06){ }^{13}$ Furthermore, we note that the inclusion of insignificant variables in our model creates a small upward bias in our standard errors; for example, when we exclude the year dummies-which do not appear in the tables for parsimony-we find that the significance level of the proportion of export-oriented new ventures in model 11 changes to 0.04 , which further corroborates hypothesis 9 . The relatively weak effect of a country's proportion of export-oriented new ventures on its total entrepreneurial activity may be partially due to our use of a 1-year time lag in Table 4; because data about a country's exportoriented new ventures were collected by the GEM as recently as 2002, only a limited number of data points are available for this variable, and the use of longer time lags is not feasible.

\section{Discussion}

Extant literature suggests that firms' entry into foreign markets can be very difficult, especially for new ventures that lack necessary resources, such as firsthand information about foreign tastes and distribution channels (Autio et al. 2000; Eriksson et al. 1997; McDougall and Oviatt 2000). We extend literature that typically examines the role of individual- or firmlevel factors on new ventures' international activities by considering the effect of macrolevel (i.e., country) variables. To this end, we rely on knowledge spillover literature to argue that cross-country differences with respect to the proportion of export-oriented new ventures may be the result of a country's openness to cross-border activities (Grossmann and Helpman 1991), as reflected in its level of FDI (both inward and outward) and international trade (export and import). In addition, we consider a country's proportion of export-oriented new ventures to be not only a consequence of export spillovers but also a driver of entrepreneurship spillovers that contributes to the

\footnotetext{
${ }^{13}$ We test hypothesis 9 with a one-tailed test, because the presence of a negative effect of early-stage export activity on total entrepreneurial activity does not seem likely. Also, only 12 of the 75 data points used in Table 4 belong to lowerincome countries, so a distinction between countries is not feasible.
}

overall emergence of new businesses within a country's borders (Audretsch and Keilbach 2004; Parker 2005).

Our results provide mixed support for the role of export spillover effects in shaping the proportion of export-oriented new ventures. First, in terms of the role of inward FDI, we find a positive effect in higherincome countries (model 3), but this effect disappears when we take other sources of knowledge spillovers into consideration (model 8). Furthermore, in lowerincome countries, inward FDI has a negative rather than positive spillover effect on the proportion of export-oriented new ventures (models 3 and 8 ). These findings are revealing, because significant economics literature concentrates on the role of foreign MNEs in creating economic prosperity within host countries (e.g., Barrell and Pain 1997) or increasing domestic firms' propensity to export (Aitken et al. 1997; Greenaway et al. 2004). However, this source of spillover does not appear to have a positive effect on export orientation among a host country's new ventures, perhaps because the channels for knowledge spillovers from inward FDI seem more relevant to incumbent economic players than to recently created firms. Foreign MNEs may establish commercial linkages with local players that have certain reputations in the host country rather than with novices that lack legitimacy (Podolny 1993). Alternatively, new ventures may have limited capacity to absorb the knowledge provided by foreign MNEs (Cohen and Levinthal 1990) and therefore benefit less from their cooperation. In lower-income countries, this lack of absorptive capacity even appears to have a negative effect on the export orientation of new ventures. However, this negative effect should not be interpreted to imply that a country's economic development is hampered when it is exposed to high levels of inward FDI. Rather, the observed negative effect may simply mean that, in lower-income countries, knowledge from inward FDI gets more easily absorbed and realized through scale economies by larger firms and thus diverted away from export activities undertaken by new ventures (van Stel et al. 2005). We acknowledge that these explanations are somewhat speculative; further research should assess in more detail the intermediate mechanisms through which new ventures benefit, or fail to benefit, from inward FDI, as well as how these mechanisms may differ in higher- versus lower-income countries. 
Second, the positive influence of a higher-income country's outward FDI on its proportion of exportoriented new ventures (models 5 and 8) is revealing in light of the argument, upheld by some researchers, that outward FDI can harm a country's economic prosperity by transferring local production and employment to foreign countries (e.g., Jones 1996). Our study indicates that, in higher-income countries, outward FDI may benefit economic activities by stimulating new ventures' export orientation. This positive spillover, as we hypothesized, may occur because domestic MNEs in foreign markets create pull effects (Nagel 2003), from which domestic new ventures can benefit. However, we also find that the positive export spillover effect is absent in lowerincome countries, possibly because they lack the capacity, in terms of both human capital and technology, to absorb the associated knowledge fully within their new ventures (Blomström et al. 1994; Borensztein et al. 1998; Görg and Greenaway 2004). Overall, the different results for the spillover effects of outward FDI across higher- and lower-income countries provides a nuanced view of the beneficial role of outward FDI for domestic firms (Blomström and Kokko 1998; Popovici 2005).

Third, the results in models 7 and 8 show a positive spillover effect of international trade on the proportion of export-oriented new ventures in higher-income countries-an effect that is statistically more significant than that of outward FDI. Although we have argued that the channels through which export spillovers occur generally work in similar ways when they stem from international trade versus FDI (e.g., through commercial linkages or demonstration effects), new ventures may consider MNEs more "distant" economic actors. According to institutional theory, economic actors tend to imitate the behavior and practices to which they can relate most directly (Powell and DiMaggio 1991). Consequently, an exporting decision may be influenced more by the exposure to "simple" international trade rather than to complex FDI activities. We also note, however, that, similar to the case of outward FDI, we find no evidence for such a positive export spillover effect of international trade in lower-income countries, perhaps again because of the limited absorptive capacity in these countries (Durham 2004; Görg and Greenaway 2004).

Fourth and finally, we find support for the spillover effect of a country's proportion of export-oriented new ventures on a country's total level of entrepreneurial activity. Export activity by new ventures may provide successful role models for aspiring entrepreneurs and thus function as a catalyst for new business creation (Davidsson and Honig 2003; De Clercq and Arenius 2006). In this sense, we identify a particular type of entrepreneurship spillover that stems from export activity (Parker 2005). This finding also extends prior research that seeks to understand the determinants of a country's level of entrepreneurship (e.g., Gavron et al. 1998; Noorderhaven et al. 2004; Storey 1999; Thurik and Wennekers 2004; van Stel et al. 2005). To the best of our knowledge, our study is the first to examine the link between the type and level of a country's early-stage entrepreneurial activity. The type of early-stage activity that entrepreneurs choose clearly has important implications for an economy's well-being (Baumol 1990). Our study suggests that an important mechanism through which new ventures affect economic prosperity at the country level may emerge through the positive spillover effect of new ventures' export orientation on the subsequent emergence of more new businesses within the country's borders.

\subsection{Limitations and future research}

Although this study provides important insights into what determines a country's proportion of exportoriented new ventures (and total level of entrepreneurial activity), it also suffers from some limitations. These limitations, in turn, open avenues for future research. First, we focus on only one particular aspect of "productive" activity among new ventures (Baumol 1990; Bowen and De Clercq 2008), namely, the extent to which they engage in substantial export activity. Although export represents an important dimension of early-stage international activities (e.g., Burpitt and Rondinelli 2000; Johanson and Vahlne 1990), it would be interesting to examine knowledge spillover effects on other facets of international involvement, such as foreign licensing, franchising, or even FDI (Eriksson et al. 1997). Furthermore, the vast body of research on the impact of technology spillovers on economic growth (e.g., Blalock and Veloso 2005; Feinberg and Majumdar 2001; Glass and Saggi 1998) offers a means for entrepreneurship researchers to include alternative dimensions of productive activities (e.g., innovation) that result 
from FDI and international trade. Such an approach would provide a more encompassing view of how countries' openness to FDI and international trade influences new ventures' potential contribution to economic prosperity.

Second, our data set covers only a relatively short period of time, particularly with regard to the variables drawn from GEM, so our analyses are largely static. Additional research would benefit greatly from longitudinal data that span a longer period of time and thus incorporate dynamic elements into the hypothesized relationships. In particular, further research could use time lags greater than a year to examine the spillover effect of exportoriented new ventures on long-term entrepreneurial activity, because such spillovers may manifest themselves more strongly over time.

Third, in the theory and hypotheses sections, we discuss several channels through which spillovers may occur for new ventures that aspire to engage in export activities (e.g., commercial linkages, prior employment with foreign firms). However, we do not empirically measure these channels. Although the intangible nature of export spillovers makes an empirical assessment of the channels through which spillovers operate challenging (Greenaway et al. 2004), research should provide more insight into the specific effects generated by various types of spillover channels on new ventures' export orientation. Moreover, the importance of different spillover channels may be contingent on the specific source of the spillovers (e.g., FDI versus international trade).

Fourth, because we focus on aggregate countrylevel spillover effects, we may have omitted some important industry-level effects. Literature on technology spillovers traditionally focuses on the industry level (e.g., Bernstein and Nadiri 1988; Cohen and Klepper 1996), including a large body of research examining whether spillovers within versus between industries are more effective for economic growth (e.g., Frenken et al. 2007; Glaeser et al. 1992; Jacobs 1969; van Stel and Nieuwenhuijsen 2004). Similarly, in the context of our study, new ventures' involvement in export activities may depend on knowledge flows from other companies active in the same sector of the economy. By ignoring industry-specific factors, we implicitly assume that the mechanisms through which export spillovers work for new ventures are identical across industries. Additional research could examine the extent to which the strength of spillover effects on new ventures' export practices depends on important industry characteristics, such as maturity level or competition. Finally, researchers could compare the effect of vertical spillovers (i.e., between suppliers and buyers within an industry) versus horizontal spillovers (i.e., between equals across industries) on new ventures' export decisions.

\subsection{Implications}

This study also offers some practical implications. First, entrepreneurs located in higher-income countries who want to become important players in the international arena should locate in areas where other international players are concentrated, especially those that engage in outward FDI and international trade. From a country-level perspective, governments that hope to encourage export activities among new ventures may benefit from creating geographical zones specifically reserved for internationally oriented firms (Din 1994). Our findings imply that such zones in higher-income countries may help reduce the costs encountered by new ventures when they break into foreign markets.

Second, governments traditionally focus on stimulating export activity among domestic firms and attracting inward FDI to generate economic growth (Ghauri and Oxelheim 2003; Greenaway et al. 2004; Molnar 2003). Furthermore, even when national instruments for promoting outward FDI exist, they tend to be part of developed countries' policy toward poorer countries (Hessels and Prince 2005). Our study suggests that, in higher-income countries, domestic economies may benefit if governments also promote outward FDI. An increased level of outward FDI, combined with international trade, increases the extent to which new ventures engage in export activities, which ultimately could foster economic prosperity (Hessels and van Stel 2007).

Third, the lack of positive export spillovers in lower-income countries suggests that, in addition to stimulating FDI and international trade, governments should stimulate the capacity for the economy, and new ventures in particular, to absorb and exploit the knowledge associated with these efforts, with respect to both the human capital of its entrepreneurial base (e.g., requisite skills to engage in export activity) and 
the structure of its economy (e.g., technology-based activities that lend themselves better to exporting). Because in lower-income countries inward FDI may naturally contribute more to the development of scale economies in larger firms rather than in new ventures (Wennekers et al. 2005), efforts could be undertaken to also channel the knowledge provided by foreign MNEs toward new ventures in these countries.

\subsection{Conclusion}

We examine the role of a country's foreign direct investment and international trade as sources of spillover effects on new ventures' export orientation and, subsequently, as a means to spur its total level of entrepreneurial activity. Our study highlights that new ventures' export orientation indeed functions as a catalyst for new business creation within a country's borders and that such an export orientation is itself influenced by a country's levels of FDI and international trade, albeit to varying degrees in higher- and lower-income countries. Overall, literature on spillovers provides a useful lens for studying macrolevel antecedents and outcomes of the extent to which a country's new ventures are export oriented. We hope then that this research leads to further investigations of the fundamental mechanisms by which a country's posture, in terms of its export orientation, may affect the nature and outcomes of its entrepreneurial undertakings.

Acknowledgements The article has been written in the framework of the research program SCALES carried out by EIM and financed by the Dutch Ministry of Economic Affairs. Previous versions of this paper have been presented at the $3 \mathrm{rd}$ GEM Research Conference, the 2006 Babson College Entrepreneurship Research Conference (Bloomington, IN) and the 2007 Academy of Management Meetings (Philadelphia, PA).

Open Access This article is distributed under the terms of the Creative Commons Attribution Noncommercial License which permits any noncommercial use, distribution, and reproduction in any medium, provided the original author(s) and source are credited.

\section{References}

Acs, Z. J., \& Amorós, J. E. (2008). Entrepreneurship and competitiveness dynamics in Latin America. Small Business Economics, 31(3) (this issue).

Acs, Z. J., Arenius, P., Hay, M., \& Minniti, M. (2004). Global entrepreneurship monitor: 2004 executive report. Babson Park, MA: Babson College.
Acs, Z. J., Audretsch, D. B., Braunerhjelm, P., \& Carlsson, B. (2006). The knowledge spillover theory of entrepreneurship. CESIS Electronic Working Paper Series, Paper No. 77.

Acs, Z. J., Audretsch, D. B., \& Feldman, M. (1994). R\&D spillovers and recipient firm size. The Review of Economics and Statistics, 76(2), 336-340.

Acs, Z. J., Desai, S., \& Hessels, J. (2008a). Entrepreneurship, economic development and public policy. Small Business Economics, 31(3) (this issue).

Acs, Z. J., Desai, S., \& Klapper, L. F. (2008b). What does "entrepreneurship" data really show? Small Business Economics, 31(3) (this issue).

Acs, Z. J., O’Gorman, C., Szerb, L., \& Terjesen, S. (2007). Could the Irish miracle be repeated in Hungary? Small Business Economics, 28(2/3), 123-142.

Aitken, B., Hanson, G. H., \& Harrison, A. E. (1997). Spillovers, foreign investment and export behavior. Journal of International Economics, 43, 103-132.

Audretsch, D. B., \& Keilbach, M. (2004). Entrepreneurship capital and economic performance. Regional Studies, 38, 949-959.

Autio, E. (2005). Creative tension: The significance of Ben Oviatt's and Patricia McDougall's article 'toward a theory of international new ventures'. Journal of International Business Studies, 36(1), 9-19.

Autio, E., Sapienza, H. J., \& Almeida, J. G. (2000). Effects of age at entry, knowledge intensity, and imitability on international growth. Academy of Management Journal, 43(5), 909-924.

Banga, R. (2003). Differential impact of Japanese and U.S. foreign direct investments on exports of Indian manufacturing. Working Paper, Delhi School of Economics, India.

Barrell, R., \& Pain, N. (1997). Foreign direct investment, technological change, and economic growth within Europe. Economic Journal, 107(445), 1770-1786.

Baumol, W. J. (1990). Entrepreneurship: Productive, unproductive and destructive. Journal of Political Economy, 98(5), 893-921.

Bernstein, J. I., \& Nadiri, M. (1988). Interindustry R\&D spillovers, rates of return, and production in high-tech industries. American Economic Review, 78(2), 429-434.

Blalock, G., \& Veloso, F. (2005). Trade, technology transfer and productivity growth: The neglected role of imports. Working Paper, Cornell University, New York.

Blomström, M., \& Kokko, A. (1998). Multinational corporations and spillovers. Journal of Economic Surveys, 12(2), $1-31$.

Blomström, M., Lipsey, R. E., \& Zejan, M. (1994). What explains developing country growth? NBER Working Paper No. 4132, National Bureau of Economic Research, Inc.

Bloodgood, J. M., Sapienza, H. J., \& Almeida, J. G. (1996). The internationalization of new high-potential U.S. ventures: Antecedents and outcomes. Entrepreneurship Theory and Practice, 20(4), 61-76.

Borensztein, E., De Gregorio, J., \& Lee, J.-W. (1998). How does foreign direct investment affect economic growth? Journal of International Economics, 45(1), 115-135.

Bowen, H. P., \& De Clercq, D. (2008). Institutional context and the allocation of entrepreneurial effort. Journal of International Business Studies, 39(4), 747-767. 
Burpitt, W. J., \& Rondinelli, D. A. (2000). Small firms' motivations for exporting: To earn and learn? Journal of Small Business Management, 38(4), 1-14.

Campbell, A. J. (1996). The effects of internal firm barriers on the export behavior of small firms in a free trade environment. Journal of Small Business Management, 34(3), $50-58$.

Cantwell, J. (1989). Technological innovation and multinational corporations. Oxford: Basil Blackwell.

Cantwell, J., \& Hodson, C. (1991). Global R\&D and UK competitiveness. In M. Casson (Ed.), Global research strategy and international competitiveness (pp. 133-182). Oxford: Basil Blackwell.

Chuang, Y. C., \& Lin, C. M. (1999). Foreign direct investment, R\&D and spillover efficiency: Evidence from Taiwan's manufacturing firms. Journal of Development Studies, 35(4), 117-137.

Coe, D., \& Helpman, E. (1995). International R\&D spillovers. European Economic Review, 39(5), 859-887.

Cohen, W. M., \& Klepper, S. (1996). Firm size and the nature of innovation within industries: The case of process and product R\&D. The Review of Economics and Statistics, 78(2), 232-243.

Cohen, W. M., \& Levinthal, D. A. (1990). Absorptive capacity: A new perspective on learning and innovation. Administrative Science Quarterly, 35(1), 128-152.

Coviello, N. E. (2006). The network dynamics of international new ventures. Journal of International Business Studies, 37(5), 713-731.

Coviello, N. E., \& Jones, M. V. (2004). Methodological issues in international entrepreneurship research. Journal of Business Venturing, 19(4), 485-508.

Davidsson, P., \& Honig, B. (2003). The role of social and human capital among nascent entrepreneurs. Journal of Business Venturing, 18(3), 301-330.

De Clercq, D., \& Arenius, P. (2006). The role of knowledge in business start-up activity. International Small Business Journal, 24(4), 339-358.

De Clercq, D., Sapienza, H. J., \& Crijns, H. (2005). The internationalization of small and medium-sized firms: The role of organizational learning effort and entrepreneurial orientation. Small Business Economics, 24(4), 409-419.

Din, M. (1994). Export processing zones and backward linkages. Journal of Development Economics, 43(2), 369-385.

Djankov, S., \& Hoekman, B. (1999). Foreign investment and productivity growth in Czech enterprises. World Bank Economic Review, 14(1), 49-64.

Dunning, J. H. (1981). International production and the multinational enterprise. London: George Allen \& Unwin.

Durham, K. B. (2004). Absorptive capacity and the effects of foreign direct investment and equity foreign portfolio investment on economic growth. European Economic Review, 48(2), 285-306.

Eriksson, K., Johanson, J., Majkgård, A., \& Sharma, D. D. (1997). Experiential knowledge and cost in the internationalization process. Journal of International Business Studies, 28(2), 337-360.

Feinberg, S., \& Majumdar, S. K. (2001). Technology spillovers from foreign direct investment in the pharmaceutical industry. Journal of International Business Studies, 32(3), 421-438.
Findlay, R. (1984). Growth and development in trade models. In R. Jones \& P. Kenen (Eds.), Handbook of international economics: International trade (Vol. 1, pp. 185-236). Amsterdam: Elsevier Science.

Fosfuri, A., Motta, M., \& Rønde, T. (2001). Foreign direct investment and spillovers through workers' mobility. Journal of International Economics, 53(1), 205-222.

Frenken, K., van Oort, F. G., \& Verburg, T. (2007). Related variety, unrelated variety and regional economic growth. Regional Studies, 41(5), 685-697.

Gavron, R., Cowling, M., Holtham, G., \& Westall, A. (1998). The entrepreneurial society. London: Institute for Public Policy Research.

Gerschenberg, I. (1987). The training and spread of management know-how: A comparative analysis of multinational and other firms in Kenya. World Development, 15(7), 931-939.

Ghauri, P., \& Oxelheim, L. (2003). European Union and the race for foreign direct investment in Europe. Oxford: Elsevier.

Glaeser, E. L., Kallal, H. D., Scheinkman, J. A., \& Shleifer, A. (1992). Growth in cities. Journal of Political Economy, 100(6), 1126-1152.

Glass, A., \& Saggi, K. (1998). International technology transfer and the technology gap. Journal of Development Economics, 55(2), 369-398.

Görg, H., \& Greenaway, D. (2004). Much ado about nothing? Do domestic firms really benefit from foreign direct investment? The World Bank Research Observer, 19(2), 171-197.

Greenaway, D., Sousa, N., \& Wakelin, K. (2004). Do domestic firms learn to export from multinationals? European Journal of Political Economy, 20(4), 1027-1043.

Greene, W. (2004). Econometric analysis (5th ed.). New York: Prentice Hall.

Grossman, G. M., \& Helpman, E. (1991). Trade, knowledge spillovers, and growth. European Economic Review, 35(2-3), 517-526.

Gugler, P., \& Brunner, S. (2007). FDI effects on national competitiveness: A cluster approach. International Advances in Economic Research, 13(3), 268-284.

Henderson, R., \& Clark, K. (1990). Architectural innovation: The reconfiguration of existing product technologies and the failure of established firms. Administrative Science Quarterly, 35(1), 9-30.

Hessels, S. J. A. (2007). Innovation and international involvement of Dutch SMEs. International Journal of Entrepreneurship and Small Business, 4(3), 234-255.

Hessels, J., \& Prince, Y. (2005). International comparison of the internationalisation of SMEs. Working Paper, EIM Business and Policy Research, Zoetermeer.

Hessels, S. J. A., \& van Stel, A. J. (2007). Export orientation among new ventures and economic growth. ERIM Report Series 2007-2008, Erasmus University Rotterdam, Rotterdam.

Hymer, S. H. (1976). The international operations of national firms: A study of direct foreign investment. Boston: MIT Press.

Jacobs, J. (1969). The economy of cities. New York: Vintage.

Jaffe, A. B., \& Trajtenberg, M. (1998). International knowledge flows: Evidence from patent citations. NBER 
Working Paper No. 6507, National Bureau of Economic Research, Inc.

Jaffe, A., Trajtenberg, M., \& Henderson, R. (1993). Geographical localization of knowledge spillovers as evidenced by patent citations. Quarterly Journal of Economics, 108(3), 577-599.

Johanson, J., \& Vahlne, J. E. (1990). The mechanism of internationalization. International Marketing Review, 7(4), 11-24.

Jones, G. (1996). The evolution of international business. London: Routledge.

Katz, J., \& Gartner, W. B. (1988). Properties of emerging organizations. Academy of Management Review, 13, 429-441.

Keeble, D., Lawson, C., Smith, H., Moore, B., \& Wilkinson, F. (1998). Internationalisation processes, networking and local embeddedness in technology-intensive small firms. Small Business Economics, 11(4), 327-342.

Kneller, R., \& Pisu, M. (2007). Industrial linkages and export spillovers from FDI. The World Economy, 30(1), 105-134.

Knight, G. A., \& Cavusgil, S. T. (1996). The born global firm: A challenge to traditional internationalization theory. In S. T. Cavusgil \& T. K. Madsen (Eds.), Export internationalizing research-enrichment and challenges. Advances in international marketing series (Vol. 8, pp. 11-26). New York: JAI.

Knight, G. A., \& Cavusgil, S. T. (2004). Innovation, organizational capabilities, and the born-global firm. Journal of International Business Studies, 35(2), 124-141.

Kogut, B., \& Chang, S. J. (1991). Technological capabilities and Japanese foreign direct investment in the United States. Review of Economics and Statistics, 73(3), 401-414.

Marshall, A. (1920). Principles of economics. London: Macmillan.

McDougall, P. P., \& Oviatt, B. M. (1996). New venture internationalization, strategic change, and performance: A followup study. Journal of Business Venturing, 11(1), 23-40.

McDougall, P. P., \& Oviatt, B. M. (2000). International entrepreneurship: The intersection of two paths. Academy of Management Journal, 43(5), 902-906.

McDougall, P. P., Shane, S., \& Oviatt, B. M. (1994). Explaining the formation of international new ventures: The limits of international business research. Journal of Business Venturing, 9(6), 469-487.

Minniti, M., Bygrave, W., \& Autio, E. (2006). Global entrepreneurship monitor: 2005 executive report. London, UK: London Business School.

Moen, O. (2002). The born globals: A new generation of small European exporters. International Marketing Review, 19(2), 156-175.

Molnar, K. (2003). Australian export promotion in a global era. Working Papers GOV2003-3, The University of Sydney, Sydney.

Nagel, A. (2003). Beyond Knut Holt's fusion model: Balancing market pull and technology push. International Journal of Technology Management, 25(6/7), 614-622.

Narula, R., \& Marin, A. (2003). FDI-spillovers, absorptive capacities and human capital development: Evidence from Argentina. MERIT-Infonomics Research Memorandum Series, Maastricht.

Noorderhaven, N., Thurik, A. R., Wennekers, A. R. M., \& van Stel, A. J. (2004). The role of dissatisfaction and per capita income in explaining self-employment across 15 European countries. Entrepreneurship Theory and Practice, 28(5), 447-466.

Ogbuehi, A. O., \& Longfellow, T. A. (1994). Perceptions of U.S. manufacturing SMEs concerning exporting: A comparison based on export experience. Journal of Small Business Management, 32(4), 37-47.

Oviatt, B., \& McDougall, P. (1994). Toward a theory of international new ventures. Journal of International Business Studies, 25(1), 45-62.

Oviatt, B. M., \& McDougall, P. P. (1995). Global start-ups: Entrepreneurs on a worldwide stage. The Academy of Management Executive, 9(2), 30-44.

Oviatt, B. M., \& McDougall, P. P. (1997). Challenges for internationalization process theory: The case of international new ventures. Management International Review, $37(2), 85-99$.

Parker, S. C. (2005). The economics of entrepreneurship: What we know and what we don't. Foundations \& Trends in Entrepreneurship, 1(1), 1-55.

Podolny, J. M. (1993). A status-based model of market competition. American Journal of Sociology, 98(4), 829-872.

Popovici, I. (2005). Outward R\&D and knowledge spillovers: Evidence using patent citations. Working Paper No 516, Department of Economics, Florida International University, Florida.

Powell, W. W., \& DiMaggio, P. J. (1991). The new institutionalism in organizational analysis. Chicago: University of Chicago Press.

Rennie, M. W. (1993). Global competitiveness: Born global. The McKinsey Quarterly, 4, 45-52.

Requena-Silvente, F. (2005). The decision to enter and exit foreign markets: Evidence from UK SMEs. Small Business Economics, 25(3), 237-253.

Reynolds, P., Bosma, N., Autio, E., Hunt, S., De Bono, N., Servais, I., et al. (2005). Global entrepreneurship monitor: Data collection design and implementation 1998-2003. Small Business Economics, 24(3), 205-231.

Reynolds, P. D., \& Miller, B. A. (1992). New firm gestation: Conception, birth and implications for research. Journal of Business Venturing, 7(5), 405-417.

Rialp, A., Rialp, J., \& Knight, G. A. (2005). The phenomenon of early internationalizing firms: What do we know after a decade (1993-2003) of scientific inquiry? International Business Review, 14(2), 147-166.

Romer, P. (1986). Increasing returns and long-run growth. Journal of Political Economy, 94(5), 1002-1037.

Romer, P. (1990). Endogenous technological change. Journal of Political Economy, 98(5), S71-S102.

Sapienza, H. J., De Clercq, D., \& Sandberg, W. R. (2005). Antecedents of international and domestic learning effort. Journal of Business Venturing, 20(4), 437-457.

Shane, S., \& Venkataraman, S. (2000). The promise of entrepreneurship as a field of research. Academy of Management Review, 25(1), 217-226.

Sjoholm, F. (1996). International transfer of knowledge. The role of international trade and geographic proximity. Weltwirtschaftliches Archiv, 132(1), 97-115.

Sternberg, R., \& Wennekers, A. R. M. (2005). Determinants and effects of new business creation: Investigations using 
global entrepreneurship monitor data. Small Business Economics, 24(3), 205-231.

Storey, D. J. (1999). Six steps to heaven: Evaluating the impact of public policies to support small business in developed economies. In D. L. Sexton \& H. Landström (Eds.), Handbook of entrepreneurship (pp. 176-194). Oxford: Blackwell.

Terjesen, S., O'Gorman, C., \& Acs, Z. J. (2008). Intermediated mode of internationalization: New software ventures in Ireland and India. Entrepreneurship \& Regional Development, 20, 89-109.

Thurik, A. R., \& Wennekers, A. R. M. (2004). Entrepreneurship, small business and economic growth. Journal of Small Business and Enterprise Development, 11(1), 140-149.

UNCTAD. (2006). World Investment Report 2006. FDI from developing and transition economies: Implications for development. New York: United Nations.

van Stel, A. J., Carree, M., \& Thurik, A. R. (2005). The effect of entrepreneurial activity on national economic growth. Small Business Economics, 24(3), 311-321.

van Stel, A. J., \& Nieuwenhuijsen, H. R. (2004). Knowledge spillovers and economic growth: An analysis using data of
Dutch regions in the period 1987-1995. Regional Studies, 38(4), 393-407.

Verheul, I., Wennekers, A. R. M., Audretsch, D. B., \& Thurik, A. R. (2002). An eclectic theory of entrepreneurship. In D. B. Audretsch, A. R. Thurik, I. Verheul \& A. R. M. Wennekers (Eds.), Entrepreneurship: Determinants and policy in a european-US comparison (pp. 11-81). Boston: Kluwer Academic.

Wang, J.-Y., \& Blomström, M. (1992). Foreign investment and technology transfer: A simple model. European Economic Review, 36(1), 137-155.

Wennekers, S., van Stel, A., Thurik, R., \& Reynolds, P. (2005). Nascent entrepreneurship and the level of economic development. Small Business Economics, 24(3), 293-309.

Zahra, S. A., Ireland, R. D., \& Hitt, M. A. (2000). International expansion by new venture firms: International diversity, mode of market entry, technological learning, and performance. Academy of Management Journal, 43(5), 925-950.

Zahra, S. A., Neubaum, D. O., \& Huse, M. (1997). The effect of the environment on export performance among telecommunications new ventures. Entrepreneurship Theory and Practice, 22(1), 25-46. 